\title{
To Be or Not to Be... a Professional Puppeteer
} Ser ou não ser... um marionetista

Anca Doina Ciabotaru ${ }^{1}$ 


\section{Abstract}

What is the professional training for the puppeteer? In this report I present a perspective of the different possibilities of training of this professional in Romania.

Keywords: Professional puppeteer; training of the puppeteer; animation theatre

\section{Resumo}

Qual a formação profissional para o marionetista? Neste relato exponho uma perspectiva das diferentes possibilidades de formação deste profissional na Romênia.

Palavras-chave: Marionetista profissional; formação do marionetista; teatro de animação

\footnotetext{
${ }^{1}$ Associate Professor, Dr. habil, at the "George Enescu" National University of Arts in laşi, head of the Theatre Department, editor-in-chief of the magazine "Theatrical Colloquia". Actor - puppeteer, creative producer of children and youth theatre performances, author of numerous books and studies on the history and aesthetics of puppet and animation theatre, the usage of theatrical techniques in education, communication, or conflict management, which have been presented at conferences or published in specialized magazines. Roumania.
} 
Being a professional puppeteer implies - theoretically and practically - two determining aspects: a specific training and being paid for making this art. Traditional or avant-garde, regardless of time or space-time coordinates, animation theatre is defined not just by the structure of stage expression, but also by the formulas of the puppeteers' training and their statute. Moving away from tradition to avant-garde depends on the way the disciple's style splits with the master's.

The training of the puppeteer (and not just their training) requires that one uses TODAY the techniques of a mythical YESTERDAY, for a mythical TOMORROW! Accepting this hypothesis, his education or his constant training/ improvement becomes a challenging process, in which the trainer/mentor lives with this paradox: he will not achieve notoriety unless his disciples find their own way, but he trains them by showing them the path he has walked himself. The techniques used for building and animating puppets have become more varied due to these splits - between what one is given during their initiation in the art of puppetry, and what they will give during their whole professional journey.

Thus, the avant-garde becomes a reformed, synthetic re-reading of tradition. This distancing is possible only if the puppeteer admits that this will not mean a betrayal of the unchangeable values of his art and of the community he is part of, which - in fact - pays him. Linking the axis of his personal values to that of the public is the aspect that determines the acceptance of the inter-conditioning between the puppeteer's values and his statute; a lack of congruence between these would generate... kitsch. Art can only be born from the wish to search, to develop and to improve the form of expression that can represent the puppeteer's identity, in agreement to his aesthetic program, as well as his level of awareness.

As a matter of fact, studies in the field of personal development and learning techniques have emphasized the fact that "our results do not represent our potential, but rather our current level of awareness of our potential." Therefore, ethnical training becomes a necessary, but not sufficient, condition; there are three more variables in this equation: intuition, creativity, awareness. Although all puppeteers have the same six mental faculties: perception, reason, memory, will, intuition, imagination, not all of them are aware of the way in which they are using them. No matter how paradoxical it may seem, even puppeteers can wonder: "What do you mainly use - intuition or reason?"

The art of animation theatre is born not just from the puppeteers' wish to perform (making art for art's sake), but also from their wish to be successful, to express themselves and to make meaningful creations. In correlating this aspect with their professional training, when establishing their objectives, their dreams puppeteers will have to choose between LIVING THE FUTURE and THE COMFORT OF ACQUIRED EXPERIENCE/ LEARNED TECHNIQUES. The option makes the difference... it can determine success. Given these conditions, a new question arises: what type of training can assure success:

1. Traditional training, based on the relationship between parent/master and apprentice - used in traditional family/clan theatre? 
2. Technical training, based on the aesthetical program of a theatre group/ institution?

3. University training, based on a mission/vision from a program that is subordinated to an educational policy?

4. Self-training, based on intuition and passion?

Here are several examples:

\section{Training that is based on tradition in/and modernity}

Pages from the journal: place: India - Jaipur (City Palace) The company's chief is a member of the orchestral duo (later, I would find out that he also knew how to build and animate marionettes); the young puppeteer/ the apprentice is out of sight, behind the pane, next to his kathputli marionettes, ready to respond to the master's requests. I lay on the stairs and I watched not a performance, but a lesson in adapting a traditional art to the demands of the hurried, yet curious spectator-visitor's demands. The Dancer, Michael Jackson (wearing a traditional mask), and The Tamer of Cobras were announced, each in their turn, and they danced; three numbers in three minutes, repeated every time there was a request. Puppeteers/ puppet makers know that they can survive only if they find multiple variants: during the day, they perform at the museum and sell puppets, and during the evenings they perform wherever they are invited - hotels, family homes, varied events.

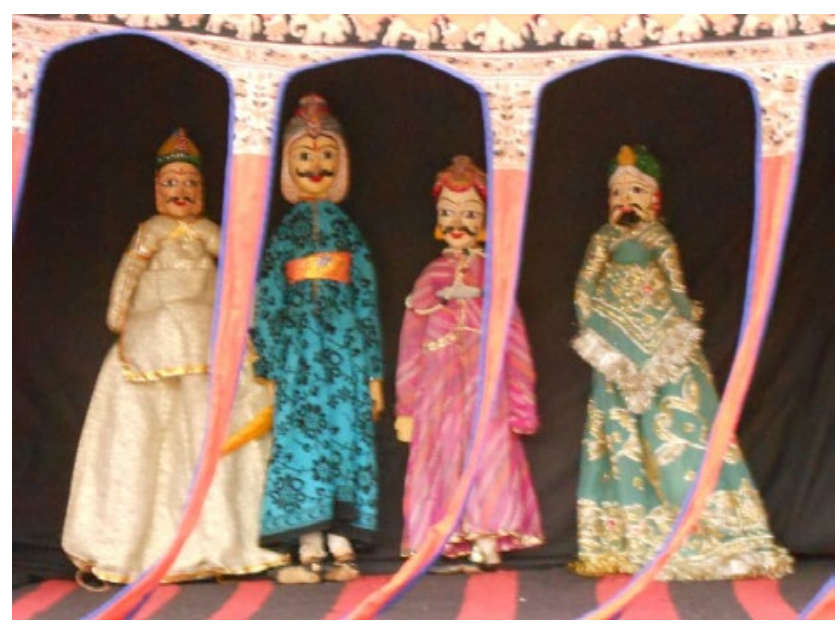

Kathputli - Jaipur - India. Collection: Inca Doina Ciobotaru

I encountered the same system in New Delhi - the company members belong to the same extended family. The musical illustration is assured by the female members, who - when they aren't performing - make the puppets' costumes (either for performances, or for sale). The capital city gives them an opportunity they do not miss: television. Because I share their craft, they showed me, as a bonus, several commercials done with puppets. I was under the impression that the spirit of tradition was closely 
followed by that of Jim Henson (1936-1990). The inside-the-clan training is a recipe that (still) works and, as a matter of fact, represents a lifestyle; no matter how caught in the myth of tradition it may seem, it is governed by the universal law of the vibration of energies specific to each period of time - which it takes from, and equally shapes in a subtle and - sometimes - unperceivable way. The puppeteer's art, just like any artist's, can only be complete when it is received by an audience which is willing to (re)pay. This rule cannot be escaped even by the puppeteer who falls in the line of tradition; no matter how strong, tradition will eventually give in to the tendencies of the times it manifests, albeit this process is conditioned by the influence of learning programs.

\section{Technical training, based on the aesthetic program of a theatre group/ institution}

This type of training has assured the development of the careers of numerous generations of Romanian puppeteers. In the years between 1950-1989, at the Tăndărică Theatre in Bucharest (though not exclusively there) there were being held stages of professional training/ "recycling" - short, intensive courses that were taught by directors, actors, choreographers with a prestigious professional activity, but... completed with courses in political ideology. Sometimes, foreign artists would be invited to hold courses of artistic mastery; for example, pantomime courses held by Marcel Marceau (1923-2007).

After 1989, even if there are numerous puppet theatres worldwide that organize short training courses for both professional and amateur puppeteers, these trainings are - partially - undertaken by universities, in the form of Master Programs... which last two years; theatre institutions (most of which are financed by the state) have abandoned organizing stages of professional training. In this context, it is worth noting that in laşi, during the International Theatre Festival for Children and Youth organized by Luceafărul Theatre yearly, there are workshops which give the opportunity of professional meetings that can disrupt routines and reanimate creative spirits.

The existence of research/creation Centres, of masterclass programs and workshops held by prestigious artists proves that, no matter the evolution of the master - apprentice relation and the new forms of mentorship it has led to, its essence has remained unchanged: the double necessity - finding and sharing knowledge; professional evolution is conditioned by the relation between the mentor's accumulated experienced and the search for new solutions, on the side of the one who is mentored.

\section{University training, based on a mission/vision from a program that is subordinated to an educational policy}

I shall give the example of a three-year training program in The Art of Acting, Puppetry, and Marionettes, held in the Faculty of Theatre at the George Enescu National University of Arts in laşi, the development of which I have been participating in for the last seventeen years. Students have the chance to learn the main animation techniques (animated objects, hand-held puppets, bunraku puppets, shadow thea- 
tre, Muppets, marionettes), as well as acting (with everything it implies: stage speech and movement, stage combat, canto etc.). Our experimental performances are creative workshops in which the student explores the possibilities of using contemporary means of expression, starting from the classical ones.

Our philosophy is: you cannot be a good puppeteer if you are not, firstly, a good actor.

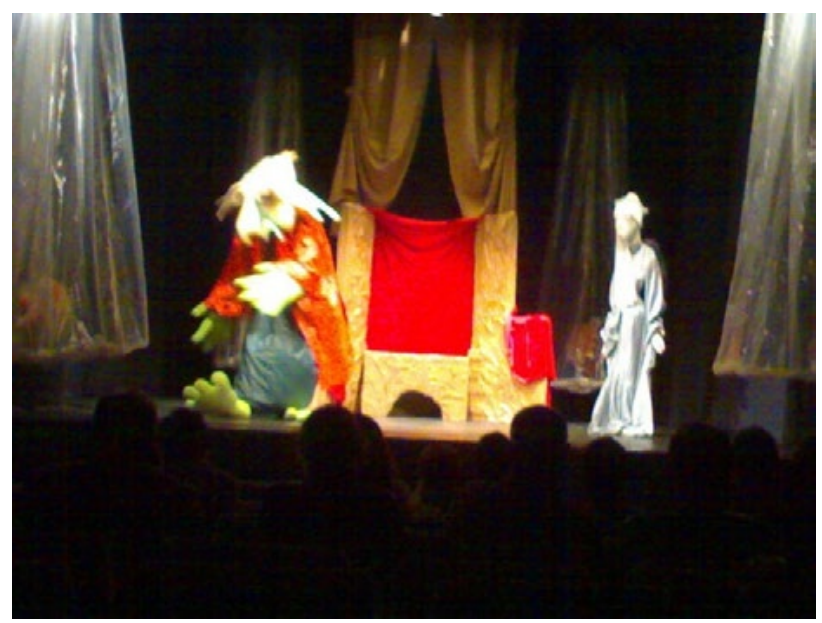

Butterfly. Directed e Collection by Anca Ciobotaru

The difference between university systems can be established by the graduates' results. It is not just budgets that make a difference, but the human resource - the teams that assure the students' training, and their willingness to continuously train themselves, to search for solutions for harmonizing artistic identities with the assumed mission.

\section{Self-training, based on intuition and passion}

This type of training closes the circle. It is exclusively determined by the puppeteer's ardent wish to be performant, to express themselves, to have an impact on the audience. Other than space-time coordinates, the puppeteer's life will be determined by the way they respond to the challenges of the social-cultural context they belong to. One of this century's key words is budget, which can become both an obsession and a challenge. How much does this production cost? Who should be in charge of raising money? If the puppeteer finds a sponsor, what should they offer in return? These obsessive questions are familiar everywhere; they seem to have conquered the world. And yet, success can impede. Analysing the relation between creativity and reaching one's maximum potential, John Maxwell, one of the best-known motivational literature authors, wrote that:

The biggest obstacle in reaching success is the fact that we rely on past successes. [...] I almost never think about all the awards and recognition I got in the past. I am happy with them, but I realize that you only get honoured for past merits. I always ask myself what I am doing in the present.

The idea is worth reflecting upon. 


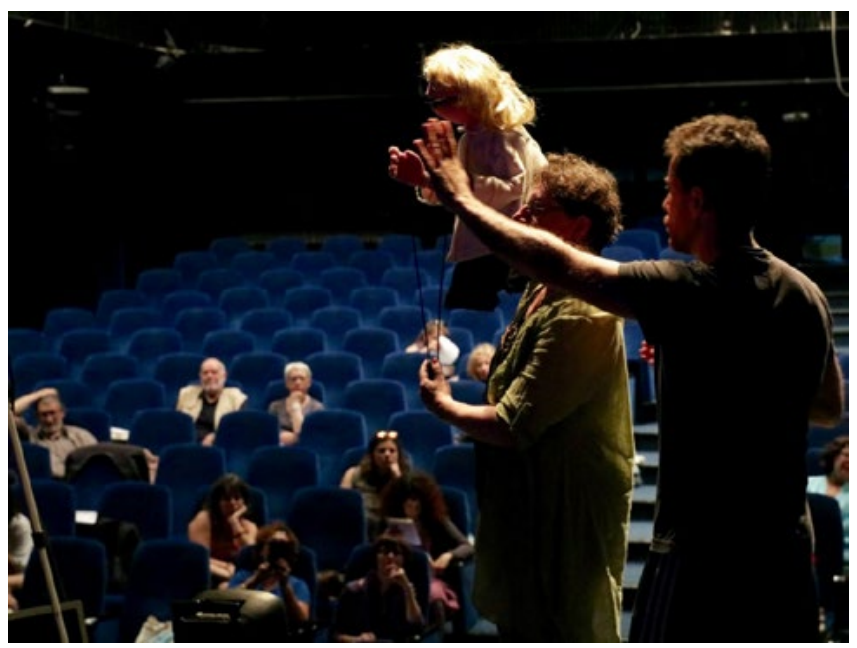

Workshop - Târgoviște, Romania. Collection: Anca Doina Ciabotaru

The trio imagination - stage image - imaginary also governs the puppeteer's art. Excessively dwelling on solving problems of reality, and not of imagination, can block creativity; discovering the "recipe for success" can be the starting point of failure, unless it is backed by continuous searching and the willingness to give up something that has previously worked. Excellence is possible only if it comes along with a beginner's restlessness and curiosity, no matter the technical level of mastery.

Starting from these examples, we can accept the fact that the history of puppet theatre is doubled by the history of the puppeteers' professional training. No matter the type of training, the technical aspects, this type of program implies approaching the puppeteer's whole personality, their every defining trait (physical endurance, ability to deal with emotions, to creatively solve problems, to build human relationships, to turn projects into reality), but also the existence of the wish to give an impact on spectators.

The first step to finding answers is... raising questions. The ideal type of professional training is the one that makes you feel fulfilled... as a HUMAN.

This text is also published in Portuguese in this issue.

Received: $29 / 06 / 2018$

Approved: $29 / 06 / 2018$ 